\title{
Clinical research of genetically modified dendritic cells in combination with cytokine-induced killer cell treatment in advanced renal cancer
}

\author{
Danhong Wang ${ }^{1}$, Bin Zhang ${ }^{1}$, Haiyan Gao' , Guoliang Ding ${ }^{2}$, Qiong Wu², Jinchao Zhang ${ }^{2}$, Li Liao ${ }^{1}$ and Hu Chen ${ }^{1 *}$
}

\begin{abstract}
Background: Renal cell carcinoma (RCC) is a malignant disease that demonstrates resistance to standard chemotherapeutic agents. Yet Active immunization using genetically modified dendritic cells holds promise for the adjuvant treatment of malignancies to eradicate or control residual disease. Cytokine-induced killer (CIK) cells are a heterogeneous population of effector $C D 8^{+}$T cells with diverse TCR specificities, possessing non-MHC-restricted cytolytic activities against tumor cells. Clinical studies have confirmed benefit and safety of CIK cell-based therapy for patients with malignancies. This clinical trial was conducted to evaluate efficacy and safety of genetically modified dendritic cells in combination with Cytokine-Induced Killer Cell (gmDCs-CIK) treatment of patients with RCC.
\end{abstract}

Methods: 28 patients with advanced renal cancer were admitted to Affiliated Hospital of Academy of Military Medical Sciences from December 2010 to March 2012 and treated by gmDCs-CIK. Clinical efficacy and safety between pre- and post-treatment were compared.

Results: This analysis showed an objective response rate (ORR) of 39\% and a disease control rate (DCR) of as $75 \%$. There is no significant relationship between clinical efficacy and whether metastasis occurred or not $(P>0.05)$. There is no significant relationship between ORR and cycles of treatment $(P>0.05)$, but DCR was significantly related with cycles of treatment $(P<0.05)$. No clinically significant side effects were observed. There were no significant changes of T cell subsets including $\mathrm{CD}^{+}, \mathrm{CD}^{+}, \mathrm{CD}^{+}, \mathrm{CD}^{+} \mathrm{CD}^{2} 5^{+}$Treg cells except Th1 in peripheral blood between day 30 after immunotherapy and 1 day before immunotherapy in 11 patients.

Conclusion: DC-CIK is feasible and effective in treating advanced renal cancer and thus provides a new approach.

Trial registration: ClinicalTrials.gov Identifier: NCT01924156. Registration date: August 14, 2013.

Keywords: Clinical research, Dendritic cells, Cytokine-Induced Killer cell, Advanced renal cancer

\section{Background}

Renal cell carcinoma (RCC) accounts for about [1] 5\% of all new cancer cases worldwide. It is estimated that 27, 0000 new cases will be diagnosed with renal cancer in the world [2] and its incidence is rising each year. Radical nephrectomy can be curative for early stage disease, but for those patients with distant metastases the prognosis is poor. After complete resection of the primary tumor, recurrence develops in another $30 \%$ of patients [3]. RCC remains a therapeutic challenge because of its resistance to

\footnotetext{
* Correspondence: chenhu217@yahoo.com.cn

1 Department of Hematopoietic Stem Cell Transplantation, Affiliated Hospital of Academy of Military Medical Sciences, Beijing, China

Full list of author information is available at the end of the article
}

conventional therapies such as radiation, chemotherapy, and hormonal therapy. Although immunotherapy using interleukin-2 (IL-2) or interferon-alpha (IFN- $\alpha$ ) [4] has become an accepted standard treatment for patients with RCC benefits, it was limited to a minority of patients. Therefore, attempts to develop more effective and nontoxic therapeutic strategies are needed. Dendritic cells (DCs) are professional antigen-presenting cells, as they are endowed with the unique potential to activate anti-tumor effector $\mathrm{T}$ and B lymphocytes [5]. They have been applied in clinics. The first study using DC vaccination for patients with RCC was published in 1999 and altogether 225 clinical trials have been published so far. Cytokine-induced killer (CIK) cells, which are non-major histocompatibility complex 
(MHC)-restricted $\mathrm{CD}^{+} \mathrm{CD}^{+} 6^{+} \mathrm{T}$ cells, take advantage of the body's natural ability to eliminate tumor cells by stimulating and restoring the immune system to recognize and kill tumor cells. The first clinical study applying autologous CIK cells for cancer therapy was performed by SchmidtWolf and colleagues in 1999 [6].

Recently, clinical trials were performed aiming at combining active immune therapy using tumor vaccines with passive immunotherapy using CIK cells [7]. Evidence is rising that the application of $\mathrm{CIK}$ cells in combination with pulsed DC may indeed improve the immune response towards cancer. To improve therapeutic potency of CIK cells by vaccination, Sun et al. made use of DCs in combination with CIK cells for the treatment of relapsed or refractory non-Hodgkin's lymphoma (NHL) [8]. After immunotherapy, the $\mathrm{CD}^{+} \mathrm{CD}^{+}: \mathrm{CD}^{+}{ }^{+} \mathrm{CD} 56^{+} \mathrm{T}$ cell ratio was improved and IFN-gamma and IL-12 levels were higher in patients of the DCs-CIK group compared to the CIK group. Tumor volume was substantially decreased. Except of transient fever and chill, no remarkable adverse events happened during or after the treatment. Although a small number of patients were treated, data imply that DCs in combination with CIK cells exhibit an improved anti-tumor immune response.

In this study, we evaluated the efficacy and safety of genetically modified DCs in combination with CIK in patients with RCC.

\section{Methods}

\section{Patient selection}

The study protocol was approved by the Institutional Review Board of the Affiliated Hospital of Academy of Military Medical Sciences. Patients were informed of the investigative nature of this study, and written consent in accordance with institutional regulations was obtained prior to study entry. Eligibility criteria were histopathologically confirmed diagnosis of advanced renal cancer (stageIIIB-IV), age more than 18 years, performance status less than 2 [9] and expected survival duration of more than 3 months; Exclusion criteria were a history of autoimmune disease, evidence of active infection, seropositivity for HIV or hepatitis B surface antigen, use of immunosuppressive agents, or pregnancy. Patients were also excluded if chemotherapy or immunomodulatory treatment had been conducted during the previous 4 weeks.

\section{Generation of DCs and CIK cells $D C s$ Vaccine preparation}

Peripheral blood mononuclear cells (PBMC) were isolated by Ficoll-Paque (PAN Biotech, Aidenbach, Germany) density gradient centrifugation that were seeded in $75 \mathrm{~cm} 3$ culture flasks at a density of $5 \times 10^{6}$ cells $/ \mathrm{ml}$ for 2 hours at $37^{\circ} \mathrm{C}$ in RPMI 1640 medium (Biowhittaker,
Verviers, Belgium). After 2 hours, the non-adherent cells were removed for the purpose of CIK culturing while adherent mono-cytes were cultured for DCs in RPMI 1640 supplemented with 1000 units/ml granulocyte macrophage colony-stimulating factor (GM-CSF; Novartis, New Jersey, USA) and interleukin-4 (IL-4) $500 \mathrm{U} / \mathrm{ml}$ (Strathmann Biotech, Hannover, Germany) for 6 days. On day 4, DCs maturation could be achieved by adding $100 \mathrm{ng} / \mathrm{ml}$ tumor necrosis factor- $\alpha$ (TNF- $\alpha$ ) (R\&D Systems, Minneapolis, MN,USA); On day 6, DCs were pulsed with RNA encoding antigen muc-1 and survivin. On day 7 , DCs were harvested, washed, and suspended again to a final concentration of $1-9 \times 10^{7}$ cells $/ \mathrm{ml}$ in saline solution for injection.

\section{Generation of CIK}

Non-adherent cells were prepared in CIK medium (RPMI 1640 medium containing $500 \mathrm{U} / \mathrm{ml} \mathrm{rhIL-2}$ and $100 \mathrm{ng} / \mathrm{ml} \mathrm{IFN- \gamma}$ (Hofman La Roche), $50 \mathrm{ng} / \mathrm{ml}$ AntiCD3 (e-Bioscience) at the density $(3-5) \times 10^{6} / \mathrm{ml}$, and then were seeded in $2 \mathrm{~L}$ culture bag. Cells were incubated in a humidified atmosphere of $5 \% \mathrm{CO}^{2}$ at $37^{\circ} \mathrm{C}$. CIK medium was changed or added according to the proliferation. CIK cells were harvested on day 11 and 13 .

\section{Phenotypic analysis}

The phenotype of DCs and CIK was determined by flow cytometry using a FACSCalibur (Becton Dikinson, San Jose, CA, USA). Cell staining was performed using FITCor PE-conjugated mouse antibodies against $\mathrm{CD} 80^{+}, \mathrm{CD} 86^{+}$, MHCII, CD $83^{+}$and $\mathrm{CD} 14^{+}$(Immunotech, Westbrook, ME, USA) for DCs, as well as $\mathrm{CD}^{+}, \mathrm{CD}^{+}, \mathrm{CD}^{+} \mathrm{CD} 56^{+}$ (PharMingen, San Diego, CA, USA) for CIK. For staining, $1 \times 10^{5} \mathrm{DCs}$ or CIK cells were suspended in $100 \mu \mathrm{l}$ of PBS and were incubated with $10 \mu \mathrm{l}$ of the antibodies for 30 minutes at $4^{\circ} \mathrm{C}$.

\section{Immunization protocol}

Patients received four subcutaneous injections of 2-5 $\times 10^{7}$ cells of Gene-Modified DCs at groin, axilla and neck on days $7,9,11$, and 13 respectively; patients received i.v. infusion of $2-5 \times 10^{10} \mathrm{CIK}$ on both days 11 and 13. IL-2 $\left(2\right.$ million $\left.\mathrm{IU} / \mathrm{m}^{2}\right)$ was administered every other day during 2-weeks interval. Each cycle of immunotherapy consisted of 4 injections of DCs and 2 injections of CIK.

\section{Evaluation of T lymphocytes subset}

For evaluation of the immune status of RCC patients, $\mathrm{CD}^{+}, \mathrm{CD}^{+}, \mathrm{CD} 8^{+}, \mathrm{CD} 4^{+} / \mathrm{CD} 8^{+}$ratio, $\mathrm{CD} 4^{+} \mathrm{CD} 25^{+}$Treg cells and Th1/Th2 cell were determined by FCM from peripheral blood 1 days before immunotherapy and on day 30 after immunotherapy. 


\section{Objectives}

The primary objective of the study is to determine the feasibility and safety of gmDCs-CIK cell treatment in RCC. The secondary endpoints were the overall response rate (ORR) and disease control rate (DCR). Patients were assessed serially using computed tomography of chest, abdomen and technetium bone scan. Clinical responses to vaccination were evaluated according to the World Health Organization criteria. Complete response (CR) was defined as complete disappearance of all clinically detectable disease. Partial response (PR) was defined as $\geq 50 \%$ decrease in the sum of the products of the two longest perpendicular diameters of all measurable lesions without the appearance of new lesions. Stable disease (SD) was defined as $25 \%$ increase or $50 \%$ decrease in tumor size. Progressive disease (PD) was defined as $\geq 25 \%$ increase in existing lesions or the appearance of a new metastasis.

\section{Advert effects}

Toxicities were graded according to National Cancer Institute Common Toxicity Criteria (NCI-CTC, version 2.0).

\section{Statistical methods}

Relationship between metastatic status and ORR/DCR as well as treatment cycles and ORR/DCR were evaluated with Fisher's exact test. Th1/Th2 and T cell subsets were analyzed with either paired-t tests or nonparametric Wilcoxon signed-rank tests based upon the normality of data. A value of $\mathrm{p}<0.05$ was considered significant. The SPSS 16.0 software package (SPSS, Inc.) was used.

\section{Results}

\section{Patient characteristics and phenotypic analysis}

From December 2010 through March 2012, 28 patients (mean age: 51.5 years; 23 men and 5 women) with metastatic RCC with clear cell histology were enrolled, with all of them had an ECOG performance status smaller than 1 upon initial screening. Of these patients, thirteen patients received one cycle of immunotherapy, seven received two cycles, five received three cycles, and two received four cycles. Demographics are summarized in Table 1.

The mature DCs phenotype was reflected by a mean percent positive value of $5.7 \pm 10.0$ for monocyte marker $\mathrm{CD}_{14}{ }^{+}, 60.4 \pm 23.7 \%$ for $\mathrm{DC}$ marker $\mathrm{CD}^{+} 3^{+}$, and $90.8 \pm$ $13.0 \%, 83.2 \pm 22.6 \%$, and $81.7 \pm 13.6 \%$ for MHCII, CD $80^{+}$, and $\mathrm{CD}^{+} 6^{+}$, respectively. Phenotypic analysis of CIK cells in 28 patients and after 11 days of culture showed that percentages of $\mathrm{CD}^{+}, \mathrm{CD}^{+} \mathrm{CD}^{+}, \mathrm{CD}^{+} \mathrm{CD}^{+}, \mathrm{CD}^{+} \mathrm{CD}^{+} 6^{+}$ cell subsets is $82.06 \% \pm 9.21 \%, 43.70 \% \pm 6.08 \%, 36.31 \pm$ $5.16 \%$, and $18.24 \% \pm 4.71 \%$, respectively.

\section{Immunologic responses to gmDCs-CIK}

Peripheral blood lymphocyte subset proportions were measured using flow cytometry. The percentage of $\mathrm{CD}^{+}$,
$\mathrm{CD}^{+} \mathrm{CD}^{+}, \mathrm{CD}^{+} \mathrm{CD}^{+}, \mathrm{CD} 16^{+} \mathrm{CD} 56^{+}$and $\mathrm{CD} 4^{+} \mathrm{CD} 25^{+}$ treg cell and $\mathrm{CD} 4^{+} / \mathrm{CD} 8^{+} \mathrm{T}$ cell ratio did not differ significantly between 1 day before immunotherapy and day 30 after immunotherapy $(P>0.05)$. There is significant difference for Th1 but not for Th2 (Figure 1) by flow cytometry.

\section{Clinical outcomes and safety}

Among all those 28 patients who were available for clinical assessment, there are $4 \mathrm{CR}$ with 2 of them more than 10 months and the other 2 more than 15 months, 7 PR (6.0-21.0 months), and 10 SD (5.0-21.0 months), 6 PD, and 1 death. ORR is $39 \%$ and DCR 75\%. Follow-up ranges from 4 to 21 months.

During the immunotherapy, no adverse events with grade greater than 2 were reported. Patients with only flu-like symptoms with fever were noticed but didn't require additional treatment (shown in Table 1).

\section{Association of ORR/DCR with other variables}

Significant correlations were not found between ORR/ DCR and metastatic site $(\mathrm{p}>0.05)$ (Table 2). However, for patients with metastasis especially from lung site, there was great reduction in tumor size after immunotherapy (Figure 2). Correlations were not found between ORR and cycles of treatment, whereas correlations were found between DCR and cycles of treatment (i.e. 1 cycle vs. more than 1 cycle) (Table 3 ).

\section{Discussion}

Treatment of RCC, especially metastatic RCCs, confronts a great dilemma in clinical practice. Although there are a number of therapeutic options available such as the immuno-regulating cytokines and the new anti-angiogenic targeted agents at present, these are commonly toxic and rarely produce durable complete remissions. The recent considerable success of cell immunotherapy in melanoma warrants further efforts to apply this treatment to other cancers including RCC.

Based on the antigen specificity of the immune system and the safety profile of cancer vaccines, the effective immunotherapy would be an ideal adjuvant, following initial clinical responses to definitive therapy [10]. In 2010, Yang B conducted autologous cytokine induced killer cells combined with IL-2 for therapy of elderly patients with B-cell malignant lymphoma [11]. The results showed that no adverse reaction was observed in all above mentioned patients. The percentages of $\mathrm{CD}^{+}$, $\mathrm{CD}^{+} \mathrm{CD}^{+}$and $\mathrm{CD}^{+} \mathrm{CD}^{+} 6^{+}$increased significantly $(\mathrm{p}<0.05)$, and serum levels of $\beta 2$-microglobulin and $\mathrm{LDH}$ were markedly decreased $(\mathrm{p}<0.05)$ after autologous CIK cell transfusion. The lymphoma symptoms were relieved with quality of life obviously elevated $(\mathrm{p}<0.01)$ in all patients. Complete remission was seen in 8 patients. In 
Table 1 Patient characteristics and response

\begin{tabular}{|c|c|c|c|c|c|c|c|c|c|}
\hline Pt \# & Gender & Histology & $\begin{array}{l}\text { Metastatic } \\
\text { disease site }\end{array}$ & Vax \# & $\begin{array}{c}\text { Clinical } \\
\text { response before } \\
\text { immunotherapy }\end{array}$ & $\begin{array}{c}\text { Clinical } \\
\text { response after } \\
\text { immunotherapy }\end{array}$ & $\begin{array}{c}\text { Additional } \\
\text { treatment before } \\
\text { immunotherapy }\end{array}$ & $\begin{array}{l}\text { Adverse effects } \\
\text { (grade) }\end{array}$ & $\begin{array}{c}\text { Survival in } \\
\text { months }\end{array}$ \\
\hline 01 & $F$ & CC & Liver & 1 & PD & PD & Sunitinib & No & $20 \mathrm{m+}$ \\
\hline 02 & M & $\mathrm{CC}$ & Lung, bone & 1 & PD & PD & None & No & $20 \mathrm{m+}$ \\
\hline 03 & M & CC & Lung, bone & 1 & PD & PR & None & No & $20 \mathrm{~m}+$ \\
\hline 04 & M & $\mathrm{CC}$ & Lung, bone & 2 & PD & SD & None & No & $19 \mathrm{m+}$ \\
\hline 05 & M & CC & Lung, Liver & 6 & SD & PR & None & No & $19 \mathrm{m+}$ \\
\hline 06 & M & CC & Bone & 4 & PD & SD & None & No & $18 \mathrm{~m}+$ \\
\hline 07 & M & CC & Bone & 1 & PD & SD & None & No & $17 \mathrm{m+}$ \\
\hline 08 & M & CC & Lung & 4 & SD & PR & None & No & $18 \mathrm{~m}+$ \\
\hline 09 & M & CC & Lung, Liver, Brain & 2 & PD & SD & None & No & $21 \mathrm{m+}$ \\
\hline 10 & M & CC & Chest & 3 & PD & SD & None & No & $16 \mathrm{m+}$ \\
\hline 11 & M & CC & Lung & 1 & PD & PR & None & No & $16 \mathrm{~m}+$ \\
\hline 12 & M & CC & Liver & 1 & PD & PD & None & Fever (grade1) & $15 \mathrm{m+}$ \\
\hline 13 & M & $\mathrm{CC}$ & Neck lymph & 1 & PD & $C R$ & None & No & $10 \mathrm{~m}+$ \\
\hline 14 & M & CC & Lung & 1 & PD & SD & None & No & $10 \mathrm{~m}+$ \\
\hline 15 & M & $\mathrm{CC}$ & Lung & 3 & PD & PR & None & No & $9 \mathrm{~m}+$ \\
\hline 16 & M & $\mathrm{CC}$ & Lung & 3 & PD & $C R$ & None & No & $10 \mathrm{m+}$ \\
\hline 17 & M & $\mathrm{CC}$ & Abdominal & 1 & PD & $C R$ & None & No & $15 \mathrm{~m}+$ \\
\hline 18 & M & CC & Lung & 1 & PD & PD & None & No & $12 \mathrm{m+}$ \\
\hline 19 & M & CC & peritoneum lymph & 1 & SD & PR & None & No & $21 \mathrm{~m}+$ \\
\hline 20 & $\mathrm{~F}$ & CC & Liver, Bone & 1 & PD & PD & None & No & $15 \mathrm{m+}$ \\
\hline 21 & $\mathrm{~F}$ & CC & Abdominal & 2 & PD & PD & None & No & $16 \mathrm{m+}$ \\
\hline 22 & M & $\mathrm{CC}$ & Bone & 2 & SD & $C R$ & sorafenib & No & $20 \mathrm{m+}$ \\
\hline 23 & M & CC & Lung, Bone & 3 & SD & SD & None & No & $6 \mathrm{~m}+$ \\
\hline 24 & $\mathrm{~F}$ & $\mathrm{CC}$ & Lung, Bone & 1 & PD & death & None & No & $4 \mathrm{~m}+$ \\
\hline 25 & M & $\mathrm{CC}$ & Lung, Liver & 3 & PD & PR & Sorafenib + Sunitinib & No & $6 \mathrm{~m}+$ \\
\hline 26 & $\mathrm{~F}$ & $\mathrm{CC}$ & Peritoneum lymph & 2 & SD & SD & None & No & $11 \mathrm{m+}$ \\
\hline 27 & M & CC & Lung, Bone & 2 & PD & SD & None & No & $5 \mathrm{~m}+$ \\
\hline 28 & M & $\mathrm{CC}$ & Lung & 2 & SD & SD & sorafenib & No & $5 \mathrm{~m}+$ \\
\hline
\end{tabular}

Abbreviations: $P T$ patient, VAX vaccination, $M$ male, $C C$ renal clear cell carcinoma, $F$ female, $S D$ stable disease, $C R$ completed response, $P R$ partial response, $P D$ progression of disease.

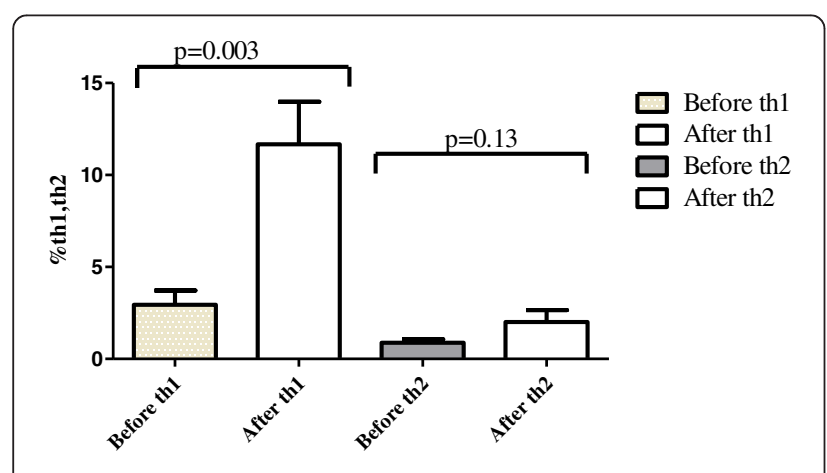

Figure 1 The changes of Th1/Th2 after treatment for 11 patients. conclusion, autologous CIK cells combined with IL-2 is safe and effective for the therapy of elderly patients with B-cell malignant lymphoma. In 2009, Thomas Schwaab and colleagues made use of autologous dendritic Cell with IL-2 therapy in RCC Patients [12]. The results showed all patients received between two and five treatment cycles.

Table 2 The relationship between ORR and cycles of immunotherapy

\begin{tabular}{|c|c|c|c|c|c|}
\hline \multirow{2}{*}{$\begin{array}{l}\text { Cycle of } \\
\text { treatment }\end{array}$} & \multicolumn{2}{|c|}{ Therapeutic effect $(n)$} & \multirow{2}{*}{ Total } & \multirow{2}{*}{$\begin{array}{l}\text { Effective } \\
\text { rate (\%) }\end{array}$} & \multirow{2}{*}{$\begin{array}{l}\text { P value (Exact } \\
\text { Sig. (2-sided) }\end{array}$} \\
\hline & Effective & No effect & & & \\
\hline 1 & 5 & 8 & 13 & 38.5 & \\
\hline$\geq 2$ & 6 & 9 & 15 & 40 & 1.000 \\
\hline Totle & 11 & 17 & 28 & 39.3 & \\
\hline
\end{tabular}




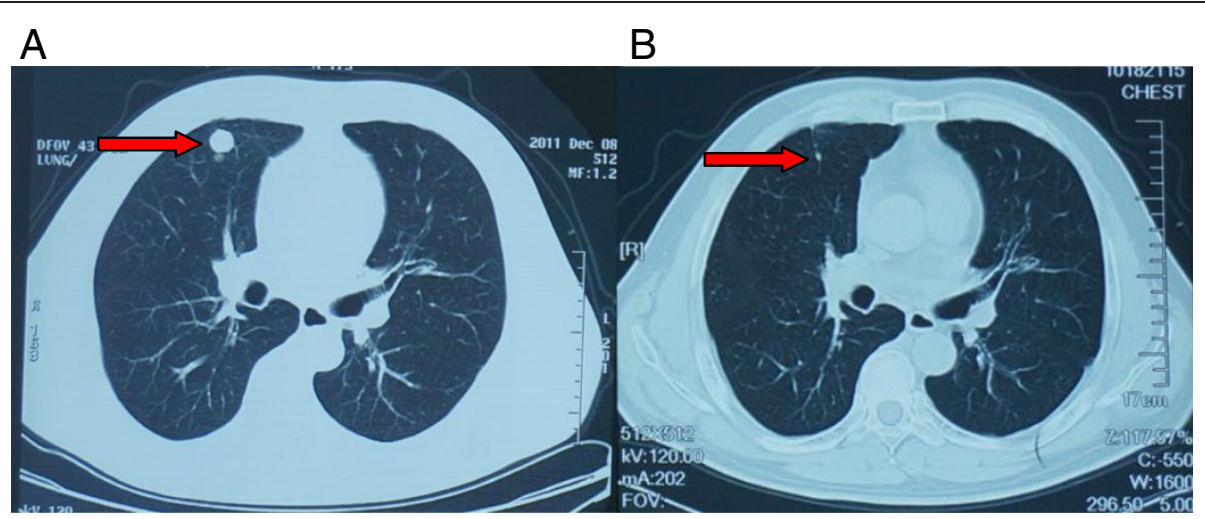

Figure 2 Clinical response to gmDCs-CIK treatment patient with renal cancer. CT scans of patient with renal cancer showing lung metastases. (A) arrow, sites are from lung metastases before gmDCs-CIK treatment, (B) arrow, sites are from lung metastases after gmDCs-CIK treatment.

Overall objective clinical response rate was $50 \%$ with three complete responses. Treatment-related changes in correlative immunologic end points were noted.

On the basis of above research reports, we propose a new combinatorial therapy approach to mobilize antitumor immunity against RCC. Our results indicate that vaccination of these patients with gmDCs-CIK is safe and efficient. We found a ORR (39\%) and a CRR (12\%) which compared favorably to the historical observations of ORR (16\%) and CR (6\%) for high-dose IL-2 or IL-2 plus IFN- $\alpha$ therapy [13-16]. In addition, Turnbull JD and his colleages had reported results of a clinical trial [17] of bevacizumab in treating mRCC showing an ORR of 9.5\% which was not superior to ORR in our study. Moreover, data of DCR is superior to other related clinical research $[18,19]$. For example, Kadono $Y$ et al. had conducted a clinical trial of IFN- $\alpha$ in systemic treatment on 15 patients with mRCC enrolled from June 2005 through September 2008 [20] showing an ORR of $7 \%$ and a DCR of $27 \%$ which is lower than our DCR of $75 \%$.

Clinical response of immunotherapy was evaluated by WHO and RESIST in a large number of clinical trial. However there is now ample evidence that these criteria do not apply to immunotherapy [21]. Immunotherapy induced tumor regressions have been well documented after initial progression and even after the appearance of new lesions, which are presumably caused by the infiltration of lymphocytes into tumours. For example, in some patients

Table 3 The relationship between DCR and cycles of immunotherapy

\begin{tabular}{cccccc}
\hline $\begin{array}{c}\text { Cycle of } \\
\text { treatment }\end{array}$ & \multicolumn{2}{l}{ Therapeutic effect (n) } & Total & $\begin{array}{c}\text { Effective } \\
\text { rate (\%) }\end{array}$ & $\begin{array}{c}\text { P value (Exact } \\
\text { Sig. (2-sided) }\end{array}$ \\
\hline 1 & 7 & 6 & 13 & 53.8 & \\
$\geq 2$ & 14 & 1 & 15 & 93.3 & $0.029^{*}$ \\
Total & 21 & 7 & 28 & 75 & \\
\hline
\end{tabular}

*P value less than 0.05 indicates statistical significance. receiving ipilimumab, metastases may grow or new lesions may even develop before there is a decline in total tumor burden. These observations have led to the proposal of novel immune-related response criteria, as response evaluation according conventional response criteria (such as WHO and RECIST) can lead to unwanted early cessation of treatment owing to initial tumor growth [22]. These observations reflect the different dynamics of the immune response compared with the direct effects of cytotoxic drugs on cancer cells [23]. This also has important implications for the design and conduct of clinical trials, such as the planning of interim analyses.

Historically, cancer immune therapies have focused on stimulation of effector cells. In the present study, we observed no obvious difference between pre-vaccination and post-vaccination in Th2 but Th1 is significant higher than pre-vaccination $(\mathrm{p}=0.003)$. Subsets of lymphocyte were evaluated in 11 patients with $\mathrm{RCC}$ treated with gmDCs-CIK. Result shows $\mathrm{CD}^{+}, \mathrm{CD}^{+}, \mathrm{CD}^{+} / \mathrm{CD}^{+}$, $\mathrm{CD} 56^{+}, \mathrm{CD} 4^{+} \mathrm{CD} 25^{+}$doesn't have significantly difference $(\mathrm{P}>0.05)$ as compared with treatment before. Th cells are central to the development of an immune response by activating antigen-specific effector cells and recruiting cells of the innate immune system [24]. Two predominant Th cell subtypes exist, Th1 and Th2. Th1 cells, characterized by secretion of IFN-gamma and TNF-alpha, are primarily responsible for activating and regulating the development and persistence of CTL. In addition, Th1 cells activate antigen-presenting cells (APC) and induce limited production of the type of antibodies that can enhance the uptake of infected cells or tumor cells into APC. Th2 cells favor a predominantly humoral response. Th1 immune response is considered more effective than $\mathrm{T}$ helper 2 (Th2) for anti-tumor immunity. In this study, Th1 is significant higher than pre-vaccination by immunotherapy which indirectly proves that the immunological effect. Most data on lymphocyte subsets in malignant disease originate from melanoma or renal cell 
carcinoma (RCC) studies. There are several studies implying that the relative amount of $\mathrm{CD} 3^{+}, \mathrm{CD} 4^{+}, \mathrm{CD} 8^{+}$, and $\mathrm{CD} 6^{+}$may be important and by reducing the tumor burden. However, only some of these studies imply that these changes can have an correlation on clinical outcome and prognosis [21]. Our results showed no correlation between recent clinical efficacy and metastatic sites from either bone or lung. This differed from results from other references for the difference of TNM staging of renal cancer, time of immune treatment, cycle of treatment, and time of testing of the peripheral blood lymphocyte subsets [25]. However, at present there is a lack of robust assays to monitor the anti-tumor immune response. Although there is an abundance of different assays that are being used to measure tumor antigenspecific $\mathrm{T}$ cell responses, these assays have not shown consistent results among trials, and none has been validated in prospective clinical trials.

\section{Conclusion}

In conclusion, genetically modified DCs in combination with CIK represent a novel immunotherapy approach for treating advanced RCC. gmDCs-CIK is safe and effective for RCC. We have revealed, for the first time, the relationship between cycle of treatment and the DCR; our study also has indicated that immunotherapy could improve the clinical efficacy of advanced renal cancer and increased frequency of immunotherapy could result in additional benefits. A larger scale clinical trial should be conducted to confirm the conclusion. Standardization of immunotherapy needs to be the focus of ongoing research.

\section{Competing interests}

The authors declare that they have no competing interests.

\section{Authors' contributions \\ DW carried out all of the assays as well as the statistical analysis and she was helped by GD in some of the procedures, such as preparation of cell culture, and analyzing the data. $\mathrm{HC}$ conceived this study and designed in the experiments. BZ, HG, QW, JZ and LL provided technical and intellectual support, participating in the results and methodological discussions. All authors helped to draft this article and read and approved the final manuscript.}

\section{Acknowledgements}

This work was supported by the Key New Drug Creation and Manufacturing Program of the "Twelfth Five-year Plan" (No. 2011ZX09102-001-29) and Clinical Feature and Application Research of Capital (No. Z111107058811107).

\footnotetext{
Author details

${ }^{1}$ Department of Hematopoietic Stem Cell Transplantation, Affiliated Hospital of Academy of Military Medical Sciences, Beijing, China. ${ }^{2}$ Cell and Gene Therapy Center, Academy of Military Medical Sciences, Beijing, China.

Received: 5 September 2013 Accepted: 3 April 2014

Published: 10 April 2014

\author{
References \\ 1. Siegel R, Naishadham D, Jemal A: Cancer statistics, 2013. CA Cancer J Clin \\ 2013, 63:11-30.
}

2. Koul H, Huh JS, Rove KO, Crompton L, Koul S, Meacham RB, Kim FJ: Molecular aspects of renal cell carcinoma: a review. Am J Cancer Res 2011, 1:240-254.

3. Motzer RJ, Hutson TE, Tomczak P, Michaelson MD, Bukowski RM, Rixe O: Sunitinib versus interferon alfa in metastatic renal-cell carcinoma. N Engl J Med 2007, 356:115-124.

4. Escudier B: Emerging immunotherapies for renal cell carcinoma. Ann Oncol 2012, 8:35-40.

5. Palucka K, Banchereau J, Mellman I: Designing vaccines based on biology of human dendritic cell subsets. Immunity 2010, 33:464-478.

6. Schmidt-Wolf IG, Finke S, Trojaneck B, Denkena A, Lefterova P, Schwella N, Heuft HG, Prange G, Korte M, Takeya M, Dorbic T, Neubauer A, Wittig B, Huhn D: Phase I clinical study applying autologous immunological effector cells transfected with the interleukin-2 gene in patients with metastatic renal cancer, colorectal cancer and lymphoma. Br J Cancer 1999, 81:1009-1016.

7. Thanendrarajan S1, Nowak M, Abken H, Schmidt-Wolf IG: Combining cytokine-induced killer cells with vaccination in cancer immunotherapy: more than one plus one? Leuk Res 2011, 35:1136-1142.

8. Sun Y, Chen J, Cai P, Hu YH, Zhong GC, Feng HZ: Therapy of relapsed or refractory non-Hodgkin's lymphoma by antigen specific dendric cells-activated lymphocytes. Zhongguo Shi Yan Xue Ye Xue Za Zhi 2010, 18:219-223

9. Yagoda A, Bander NH: Failure of cytotoxic chemotherapy,1983-1988, and the emerging role of monoclonal antibodies for renal cancer. Urol Int $1989,44: 338-345$

10. Hirschowitz E, Foody T, Hidalgo G, Yannelli J: Immunization of NSCLC patients with antigen-pulsed immature autologous dendritic cells. Lung Cancer 2007, 57:365-372.

11. Yang B, Lu XC, Zhu HL, Han WD, Wang Y, Fan H, Li SX, Liu Y, Dai HR, Yao SQ: Clinical study of autologous cytokine induced killer cells combined with IL-2 for therapy of elderly patients with B-cell malignant lymphoma. Zhongguo Shi Yan Xue Ye Xue Za Zhi 2010, 18:1244-1249.

12. Schwaab T, Schwarzer A, Wolf B, Crocenzi TS, Seigne JD: Clinical and immunologic effects of intranodal autologous tumor lysate-dendritic cell vaccine with ALdesleukin (Interleukin2) and IFN-a2a therapy in metastatic renal cell carcinoma patients. Clin Cancer Res 2009, 15:4986-4992.

13. Motzer RJ, Mazumdar M, Bacik J, Russo P, Berg WJ, Metz EM: Effect of cytokine therapy on survival for patients with advanced renal cell carcinoma. J Clin Oncol 2000, 8:1928-1935.

14. Figdor CG, de Vries IJ, Lesterhuis WJ, Melief CJ: Dendritic cell immunotherapy: mappingthe way. Nat Med 2004, 10:475-480.

15. Atzpodien J, Kirchner $H$, Jonas U, Bergmann L, Schott $H$, Heynemann $H$, Fornara P, Loening SA, Roigas J, Müller SC, Bodenstein H, Pomer S, Metzner B, Rebmann U, Oberneder R, Siebels M, Wandert T, Puchberger T, Reitz M, Prospectively Randomized Trial of the German Cooperative Renal Carcinoma Chemoimmunotherapy Group (DGCIN): Interleukin-2- and interferon alfa-2a-based immunochemotherapy in advanced renal cell carcinoma: a Prospectively Randomized Trial of the German Cooperative Renal Carcinoma Chemoimmunotherapy Group (DGCIN). J Clin Oncol 2004, 22:1188-1194.

16. Negrier S, Escudier B, Lasset C, Douillard JY, Savary J, Chevreau C, Ravaud A, Mercatello A, Peny J, Mousseau M, Philip T, Tursz T: Recombinant human interleukin-2, recombinant human interferon alfa-2a, or both in metastatic renal-cell carcinoma. Groupe Francais d'Immunothérapie. N Engl J Med 1998, 338:1272-1278.

17. Turnbull JD, Cobert J, Jaffe T, Harrison MR, George DJ, Armstrong AJ: Activity of single-agent Bevacizumab in patients with metastatic renal cell carcinoma previously treated with vascular endothelial growth factor tyrosine kinase inhibitors. Clin Genitourin Cancer 2013, 11:45-50.

18. Bukowski RM, Eisen T, Szczylik C: Final results of the randomized phase III trial of sorafenib in advanced renal cell carcinoma: survival and biomarker analysis. J Clin Oncol 2007, 25:abstract5023.

19. Escudier B, Eisen T, Stadler WM, Szczylik C, Oudard S, Staehler M, Negrier S, Chevreau C, Desai AA, Rolland F, Demkow T, Hutson TE, Gore M, Anderson S, Hofilena G, Shan M, Pena C, Lathia C, Bukowski RM: Sorafenib for treatment of renal cell carcinoma: final efficacy and safety results of the phase III treatment approaches in renal cancer global evaluation trial. J Clin Oncol 2009, 27:3312-3318.

20. Maroto JP, Del Muro XG, Mellado B, Perez-Gracia JL, Andrés R, Cruz J, Gallardo E, Domenech M, Arranz JA, Meana JA: Phase II trial of sequential 
subcutaneous interleukin-2 plus interferon alpha followed by sorafenib in renal cell carcinoma (RCC). Clin Trans/ Oncol 2013 [Epub ahead of print].

21. Lesterhuis WJ1, Haanen JB, Punt CJ: Cancer immunotherapy-revisited. Nat Rev Drug Discov 2011, 10:591-600.

22. Weber J: Ipilimumab: controversies in its development, utility and autoimmune adverse events. Cancer Immunol Immunother Nat Rev Drug Discov 2011, 10:591-600.

23. Hoos A, Eggermont AM, Janetzki S, Hodi FS, Ibrahim R, Anderson A, Humphrey R, Blumenstein B, Old L, Wolchok J: Improved endpoints for cancer immunotherapy trials. Improved endpoints for cancer immunotherapy trials. J Natl Cancer Inst 2010, 18:1388-1397.

24. Knutson KL1, Disis ML: Tumor antigen-specific Thelper cells in cancer immunity and immunotherapy. Cancer Immunol Immunother 2005, 54:721-728

25. Kraemer M, Hauser S, Schmidt-Wolf IG: Long-term survival of patients with metastatic renal cell carcinoma treated with pulsed dendritic cells. Anticancer Res 2010, 30:2081-2086.

doi:10.1186/1471-2407-14-25

Cite this article as: Wang et al: Clinical research of genetically modified dendritic cells in combination with cytokine-induced killer cell treatment in advanced renal cancer. BMC Cancer 2014 14:251.

\section{Submit your next manuscript to BioMed Central and take full advantage of:}

- Convenient online submission

- Thorough peer review

- No space constraints or color figure charges

- Immediate publication on acceptance

- Inclusion in PubMed, CAS, Scopus and Google Scholar

- Research which is freely available for redistribution 